\title{
PERBEDAAN EFEKTIFITAS PEMBERIAN VITAMIN E 100 IU DENGAN ASPIRIN 81 MG UNTUK PENCEGAHAN PREEKLAMSIA PADA PRIMIGRAVIDA
}

\section{THE DEFFERENCE OF EFFECTIVENESS OF VITAMIN E 100 IU WITH ASPIRIN 81 MG TREATMENT TO PREVENT PREEKLAMPSIA ON PRIMIGRAVIDAS}

\author{
Siti Candra Windu Baktiyani*, Imam Wahjudi** \\ * Laboratorium Farmakologi FK Unibraw Malang \\ ${ }^{* *}$ Bagian / SMF Obstetri-Ginekologi FK Unibraw / RSU dr. Saiful Anwar Malang
}

\begin{abstract}
Preeclampsia is a specific disturbance of human pregnancy, that diagnosed by the onset of hypertension and proteinuria in the third trimester. It occurs more in developing countries, due to the fact that developed countries have better prenatal care. The objective of this study was to assess the difference effectiveness of preventing preeclampsia and giving vitamin E 100 iu and aspirin $81 \mathrm{mg}$. This study used prospective with single randomaised clinical trial. The place of this study is on Maternity care unit of RSUD Dr. Saiful Anwar Malang from October 2000 to October 2001. Fourty samples primigravidas between the age of 19-35 years were used in this study. Twenty four samples were treated with vitamin $E$ and 24 samples were treated with aspirin started at the eighteenth weeks of pregnancy until delivery. The changes, of blood presure, albuminuri and oedema were observed. The result showed that during the observation the incidence rate of mild preeclampsia of vitamin $E$ was 4 samples or $(16,7 \%)$, mild preeclampsia was 1 sample or $(14,2 \%)$ by the time of the normal delivery. On the other hand, the mild preeclampsia of the control group of aspirin was 3 samples or $(12,5 \%)$ and mild preeklampsia was 2 samples or (8,3\%) at the normal delivery. There is no significant difference in preeclampsia occurance between vitamin $E$ and aspirin group.
\end{abstract}

Key words: Vitamin E, Aspirin, preeclampsia

\section{PENDAHULUAN}

Preeklampsia merupakan penyakit yang angka kejadiannya di setiap negara berbeda-beda. Angka kejadian lebih banyak terjadi di negara yang sedang berkembang dari pada di negara maju. Hal ini disebabkan oleh karena di negara maju perawatan prenatalnya lebih baik. Kejadian preeklampsia dipengaruhi oleh paritas, ras, faktor genetik dan lingkungan. Kehamilan dengan preeklampsia lebih umum terjadi pada primigravida, sedangkan pada multigravida berhubungan dengan penyakit hipertensi kronis, diabetes melitus dan penyakit ginjal $(1,2)$.

Preeklampsia adalah timbulnya tekanan darah tinggi dalam kehamilan disertai proteinuri dan oedema pada kehamilan $\geq 20$ minggu. Preeklampsia ada 3 kriteria yaitu preeklampsia ringan bila tekanan darah $<160 / 110 \mathrm{mmHg}$, proteinuri positif $<2$, Preeklampsia berat bila tekanan darah $\geq 160 / 110 \mathrm{mmHg}$ dan protenuri positif $>2$. Sedangkan Eklampsia terjadi bila preeklampsia berat yang mengalami kejang $(1,2)$.

Dari hasil konggres Perhimpunan Obstetri dan Ginekologi Inodonesia (1985), kejadian Preeklampsia di

Jurnal Kedokteran Brawijaya, Vol. XXI, No.3, Desember 2005

Korespondensi: Siti Candra B; Laboratorium Farmakologi

Fakultas Kedokteran Unibraw; Jl. Veteran Malang 65145;

Telp. (0341) 580993 ext. 110
Indonesia kurang lebih 3,4\% - 8,5\%, sedangkan Sulchan (1983) di RS Dr Sardjito Yogyakarta mendapatkan angka yang lebih tinggi yaitu 36,1\%. Cunningham (1997) melaporkan di Rumah Sakit Parkland dari penderita preeklampsia hampir $60 \%$ pada nullipara (1). Ibu dengan Preeklampsia dan eklampsia yang melahirkan di RS Saiful Anwar Malang pada tahun 1997 adalah 7,9\% (pada primigravida kurang lebih 3,6\%) (1,3). Pada tahun 1999 di poli hamil RSSA angka preeklampsia pada primigravida yang berumur kurang dari 35 tahun dan lebih dari 19 tahun adalah $29 \%$.

Terjadinya preeklampsia dapat dideteksi secara dini dengan memakai mean arterial pressor test (MAP) dan rool over test (ROT). Sensitifitas dari MAP 93\% dan spesifisitas $62 \%$, sedangkan ROT sensitifitasnya $93 \%$ dan spesifitasnya $91 \%$. Pemeriksaan MAP pada kehamilan 18-26 minggu, ROT diperiksa pada kehamilan 28-32 minggu. Dengan cara ini, preeklampsia bisa terdeksi secara dini $(1,4)$.

Rumah Sakit Hasan Sadikin Universitas Pajajaran Bandung bekerjasama dengan Fakultas Kedokteran Nara Jepang, menggunakan kombinasi vitamin E $600 \mathrm{mg}$ dan asam dosahexanoid $80 \mathrm{mg}$ untuk mencegah preeklampsia berat pada primigravida. Dari penelitian tersebut dapat dibuktikan bahwa terjadi penurunan kejadian preeklampsia secara signifikan pada kelompok perlakuan. Di Rumah Sakit Westminster London dengan menggunakan kombinasi 
vitamin E 400 IU dan vitamin C $1000 \mathrm{mg}$ perhari dibandingkan dengan kelompok plasebo memperoleh hasil kejadian preeklampsia lebih rendah pada kelompok perlakuan. Dari data metaanalisis, aspirin dosis rendah telah direkomendasikan untuk mencegah preeklampia pada primigravida yang berisiko terjadinya preeklampsia $(5,6,7)$.

Penelitian ini menggunakan vitamin $E$ sebagai kelompok perlakuan dan aspirin sebagai kelompok kontrol yang diberikan mulai penderita datang pada kehamilan 18 minggu sampai melahirkan. Pemberian obat tersebut dimaksudkan untuk mencegah preeklampsia pada primigravida yang diduga akan mengalami preeklampsia. Tujuan dari penelitian tersebut adalah untuk menilai perbedaan efektifitas pencegahan preeklampsia dengan pemberian vitamin E $100 \mathrm{lU}$ dan Aspirin $81 \mathrm{mg}$.

\section{METODE}

Rancangan penelitian yang digunakan adalah prospektif dengan uji klinis acak tersamar tunggal. Tempat penelitian di Poli hamil RS Dr. Saiful Anwar. Penelitian dilaksanakan mulai bulan Oktober 2000 hingga Oktober 2001. Target populasi adalah Ibu primigravida yang berusia diantara 19 - 35 tahun. Sebagai sampel adalah lbu primigravida dengan kriteria inklusi usia ibu antara $20-35$ tahun, pemeriksaan MAP dan ROT positif, tidak menderita penyakit kronis, janin hidup dan ibu bersedia menjadi responden dengan menggunakan informed consent. Pengambilan sampel secara random sampling yaitu berdasarkan nomor urut sampel datang, yang ganjil menjadi kelompok A (perlakuan) yang genap kelompok B (kontrol). Besar sampel sebanyak 24. Semua data dimasukkan kedalam komputer untuk dilakukan pengkodean. Data dianalisis menggunakan uji statistik X2 test, Fisher' exact test, uji t 2 sampel bebas, kemudian mencari resiko relatif.

\section{HASIL PENELITIAN}

Selama periode November 2000 sampai Oktober 2001 jumlah subjek keseluruhan yang ikut dalam penelitian ini sebesar 53 orang, yang droup out 5 orang, sisanya 48 orang sesuai dengan besar sampel yang telah direncanakan. Dari 5 sampel yang droup out dengan berbagai sebab, diantaranya; 1 sampel bayi meninggal di dalam kandungan, 3 sampel melahirkan di luar kota dan 1 sampel hanya 2 kali kontrol menjadi PEB yang berasal dari ROT kelompok Al. Dari 48 sampel, 24 sampel mendapatkan perlakuan dan 24 sampel lainnya sebagai kontrol.

Selama penelitian ini tidak didapatkan preeklampsia berat maupun eklampsia dan hanya didapatkan preeklampsia ringan yaitu pada kelornpok perlakuan 4 sampel dan kelompok kontrol 3 sampel. Pada kelompok perlakuan dalam pengamatan didapatkan saat hamil terjadi preeklampsi ringan 1 sampel, yang mana waktu mendekati persalinan sampai persalinan menjadi kahamilan normal, sedangkan pada kelompok kontrol terdapat 2 sampel yang mengalami hal yang sama.

Adapun hasil penelitian tersebut disajikan dalam bentuk tabel, diagram dan narasi.

\section{Tabel 1. Karakteristik Sampel Mulai Pengamatan}

\begin{tabular}{llccc}
\hline No & Karakteristik & $\begin{array}{c}\text { Vitamin } \mathrm{E} \\
\mathrm{X} \pm \mathrm{SD}\end{array}$ & $\begin{array}{c}\text { Aspirin } \\
\mathrm{X} \pm \mathrm{SD}\end{array}$ & Signifikansi \\
\hline 1 & Umur & $25,17 \pm 4,32$ & $23,67 \pm 2,93$ & $\mathrm{p}=0,167$ \\
2 & Berat badan & 55,50 & 55,79 & $\mathrm{p}=0,918$ \\
3 & Usia kehamilan & $27 \pm 3,87$ & $25,254,32$ & $\mathrm{p}=0,144$ \\
4 & $\begin{array}{l}\text { Tekanan darah } \\
\text { sistole }\end{array}$ & $118,15,28$ & $113,544,77$ & $\mathrm{p}=0,003$ \\
5 & $\begin{array}{l}\text { Tekanan darah } \\
\text { diastole }\end{array}$ & $80 \pm 0$ & $80 \pm 0$ & - \\
\end{tabular}

Keterangan:

Data disajikan dalam Mean \pm SD

Uji beda dilakukan dengan uji 2 sampel bebas.

$p=<0,05$ signifikan.

Dari tabel karakteristik sampel mulai pengamatan diantara 2 kelompok, berdasarkan tekanan systole waktu mulai pengamatan didapatkan perbedaan bermakna diantara 2 kelompok $(p<0,05)$. Sedangkan yang lain tidak ada perbedaan bermakna, sehingga bisa dibandingkan diantara 2 kelompok. Karena ada perbedaan tekanan systole waktu mulai pengamatan, kami melakukan uji regresi logistik menunjukkan bahwa variable perlakuan dan sístole tidak berbeda bermakna terhadap terjadinya preeklampsia. Sistole berbeda pada saat pemberian perlakuan saja, tetapi tidak berpengaruh terhadap terjadinya preeklampsia.

Distribusi sampel berdasarkan albuminuri mulai pengamatan diantara kelompok perlakuan dan kontrol sama - sama negatip. Sedangkan distribusi sampel berdasarkan oedema mulai pengamatan kelompok perlakuan dan kontrol dengan menggunakan uji exact Fisher tidak berbeda. Dari uji MAP dan ROT mulai pengamatan menggunakan $p$ continuity correction $=1$, besar sampel diantara 2 kelompok sama. 
Diagram 1. Grafik Perubahan Tekanan Darah Sistol dan Diastol pada Kelompok Perlakuan dan Kontrol dengan Skrining MAP

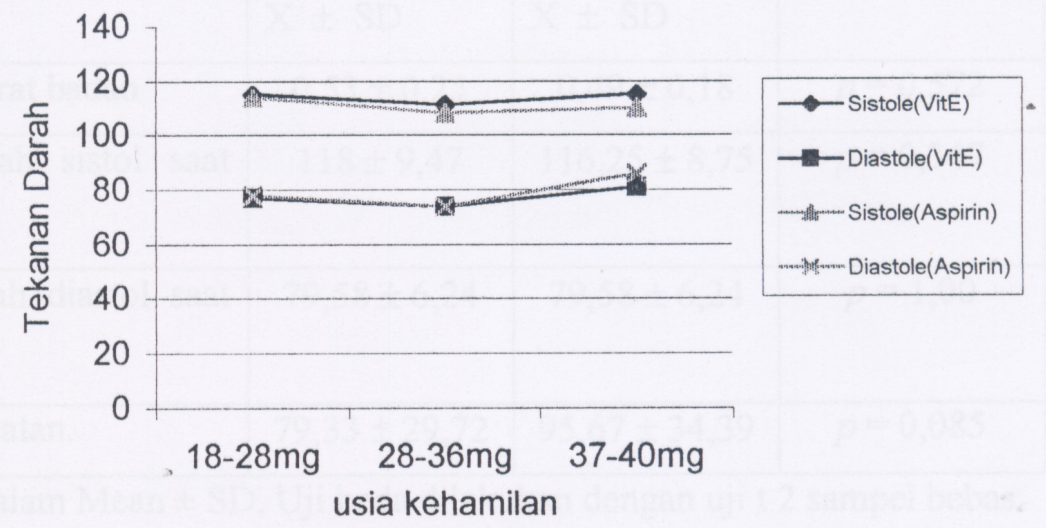

Perubahan tekanan darah diantara 2 kelompok perlakuan pada MAP tidak berbeda secara bermakna

\section{Diagram 2. Grafik Perubahan Tekanan Darah Sistol dan Diastol pada Kelompok Perlakuan dan Kontrol dengan Skrining ROT}

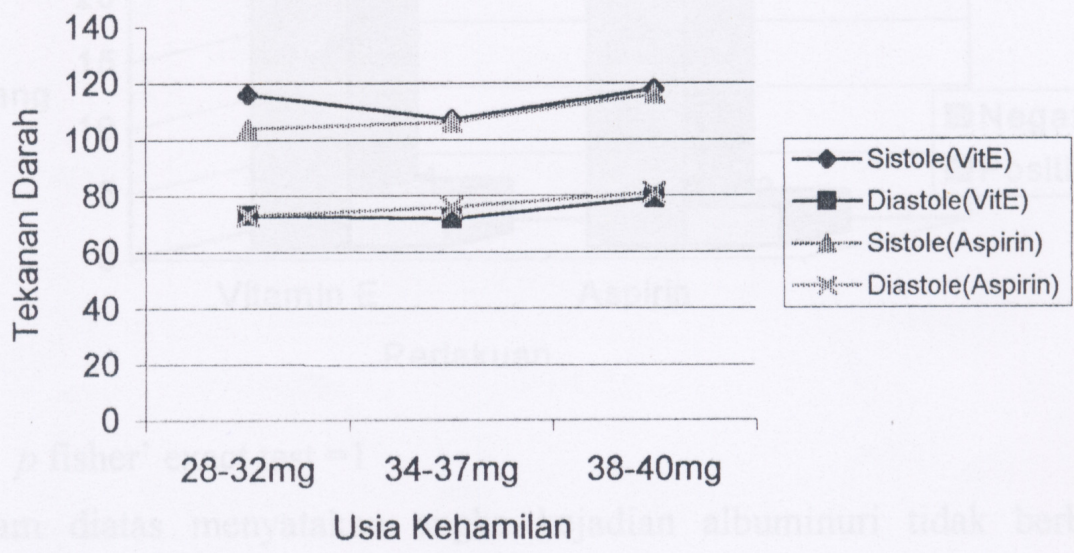

Perubahan tekanan darah diantara 2 kelompok perlakuan pada ROT tidak berbeda secara bermakna $(p>0,05)$

Tabel 2. Karakteristik sampel waktu pengamatan

\begin{tabular}{|c|c|c|c|c|}
\hline No & Karakteristik & $\begin{array}{c}\text { Vitamin E } \\
X \pm S D\end{array}$ & $\begin{array}{l}\text { Aspirin } \\
X \pm S D\end{array}$ & Signifikansi \\
\hline 1 & Kenaikan berat badan & $0,53 \pm 0,25$ & $0,49 \pm 0,18$ & $p=0,572$ \\
\hline 2 & Tekanan darah sistole saat melahirkan & $118 \pm 9,47$ & $116,25 \pm 8,75$ & $p=0,347$ \\
\hline 3 & Tekanan darah diastole saat melahirkan & $79,58 \pm 6,24$ & $79,58 \pm 6,24$ & $p=1,00$ \\
\hline 4 & Lama pengobatan & $79,33 \pm 29,72$ & $95,67 \pm 34,39$ & $p=0,085$ \\
\hline
\end{tabular}

Keterangan: Data disajikan dalam Mean \pm SD, Uji beda dilakukan dengan uji t 2 sampel bebas. $p=<0,05$ signifikan.

Dari tabel karakteristik diatas selama pengamatan tidak ada perbedaan bermakna diantara 2 kelompok perlakuan.

Diantara 2 kelompok perlakuan kadar albuminuri saat melahirkan tidak berbeda bermakna dengan $p F$ isher'exact test $=1$. Keadaan oedema kaki saat melahirkan dengan $p$ continuity correction $=0,06171$ menunjukkan tidak berbeda secara bermakna. Distribusi sampel berdasarkan yang pernah preeklampsia ringan kemudian membaik dalam pengamatan antara kelompok vitamin $E$ dengan aspirin tidak berbeda bermakna dengan $p F$ isher'exact test $=1$. Angka kejadian preeklampsia pada kelompok Vitamin $\mathrm{E}$ sebesar 4 sampel dan pada kelompok aspirin 3 sampel dengan $p$ Fisher' exact test $=1$ dan Resiko Relatif $(R R)=$ 1,33, Cl 95\% (0,46809 - 2,13633). Resiko Relatif untuk terjadinya preeklampsia pada pemberian vitamin E 1,33 kali lebih besar daripada pemberian aspirin. 


\section{DISKUSI}

Arteri spiralis pada kehamilan normal diinvasi oleh sel-sel trophoblast. Invasi ini akan menyebabkan dinding arteri spiralis menjadi elastis dan tonusnya menurun sehingga mudah untuk berdilatasi. Hal ini akan meningkatkan aliran darah ke plasenta. Di samping itu arteri spiralis menjadi refrakter terhadap baban vasomotor. Salah satu teori yang diakui dapat menjelaskan dasar terjadinya preeklampsia yaitu teori radikal bebas atau oksidan. Radikal bebas ini dihasilkan oleh jaringan yang mengalami iskernia. Pada preeklampsia, sumber radikal bebas yang utama ialah plasenta (8 - 14).

Pada awal kehamilan ibu yang menderita preeklampsia terjadi peningkatan rasio very low density lipoprotein terhadap toxicity preventing activity (VLDL/TxPA). Peningkatan ini menyebabkan invasi trophoblast ke arteri spiralis menjadi kurang sempurna di bagian sepertiga miometrium, sehingga arteri spiralis tersebut masih mempertahankan kontraktilitasnya. Invasi sel trophoblast ke arteri spiralis yang kurang sempuma ini, menyebabkan tonus pembuluh darah tetap tinggi dan seolah - olah terjadi vasokontriksi. Dengan demikian pembuluh darah ibu tidak mampu memenuhi kebutuhan darah ke plasenta, sehingga terjadi iskernia yang pada akhirnya menyebabkan hipoksia plasenta $(1,11,12,13)$.

Pada ibu primigravida yang cenderung menderita preeklampsia mulai terjadi iskemia plasenta mulai kehamilan 16 minggu. Iskemia plasenta melepaskan suatu bahan yang bersifat toksik yaitu radikal bebas. Molekul radikal bebas ini akan menyerang lemak tak jenuh di membran sel yang banyak dijumpai pada plasenta. Efek ini akan mengakibatkan proses yang dikenal dengan peroksidasi lemak dan selanjutnya peroksidasi lemak akan menghasilkan suatu senyawa yang sangat toksik yaitu lemak peroksida $(6,7)$.

Peningkatan peroksida lemak akan meningkatkan konsumsi vitamin $\mathrm{E}$, dengan demikian menurunkan kadar vitamin $E$. Vitamin $E$ dapat berfungsi sebagai peredam radikal bebas dan menetralkan radikal bebas lebih efektif daripada antioksidan lainnya. Pemberian vitamin E bertujuan untuk mencegah proses peroksidasi lemak, melindungi jaringan lemak dari serangan radikal bebas dan menstabilkan membran $(5,7,9,11,12,14)$.

Pada penelitian ini menggunakan vitamin $\mathrm{E}$ untuk mencegah preeklampsia. Hasil dari penelitian ini tidak terjadi preeklampsi berat maupun eklampsia, hanya terjadi preeklampsia ringan 4 dari 24 sampel atau sebesar 16,7\%. Sedangkan yang mengalami preeklampsia ringan, kemudian membaik pada waktu menjelang melahirkan sarnpai melahirkan ada 1 diantara 24 sampel atau sebesar $4,2 \%$. Pemberian vitamin $\mathrm{E}$ pada penelitian ini terbukti dapat menurunkan angka kejadian preeklarnpsia dan mencegah memberatnya preeklampsia.
Asam arakidonat merupakan bahan dasar pembentukan prostasiklin, prostaglandin, dan thromboksan melalui proses siklooksigenasi. Pembentukan thromboksan bisa dihambat pada proses siklooksigenasi dengan obat golongan NSAID (non steroidal anti inflamatory drugs) seperti aspirin $(1,11)$.

Pada kehamilan normal terjadi keseimbangan antara tromboksan dan prostasiklin untuk mempertahankan fungsi fisiologis dari vaskuler terutama pada plasenta. Prostasiklin lebih dominan dengan makin tuanya kehamilan, sedangkan kadar tromboksan secara progresif menurun $(7,11)$.

Pemberian aspirin dosis rendah $(50-150 \mathrm{mg})$ bekerja pada enzim siklooksigenase, yakni dengan cara menekan sintesis tromboksan secara selektif dan tidak terlalu berpengaruh terhadap sintesis prostasiklin. Thromboksan diketahui menyebabkan vasokontriksi dan agregasi trombosit $(10,11,15,16)$.

Pada penderita preeklampsia terjadi kebalikan rasio prostasiklin dengan tromboksan, tromboksan lebih dominan dengan semakin tuanya kehamilan. Pada penelitian ini, kami menggunakan aspirin dosis rendah sebagai kontrol untuk mencegah terjadinya preeklampsia pada primigravida. Didapatkan angka kejadian preeklampsia ringan 3 dari 24 sampel atau sebesar $12,5 \%$, sedangkan penderita yang pernah preeklampsia ringan dalam pengamatan waktu kehamilan mengalami perbaikan menjadi normal menjelang persalinan sampai persalinan 2 dari 24 sampel atau sebesar 8,3\%. Pada ibu hamil yang diberi aspirin tidak ada yang mengalami preeklampsia berat ataupun eklampsia.

Pemberian aspirin dapat menurunkan terjadinya peningkatan thromboksan. Aspirin mencegah terbaliknya rasio prostasiklin dengan tromboksan, sehingga akan mencegah dan menurunkan terjadinya preeklampsia serta memberatnya preeklampsia.

Penelitian Gant dilakukan pada primigravida dengan sekrening ROT, dari 16 sampel yang ROT (+), 15 (93\%) berkembang menjadi preeklampsia. Pada penelitian Oney dengan skrining MAP, dari 85 sarnpel yang MAP (+), 27 sampel $(32 \%)$ berkembang menjadi preeklampsia $(4,5)$. Pada penelitian ini dari kelompok perlakuan 16 sampel ROT $(+)$, yang rnenjadi preeklampsia ringan $4(25 \%)$, sedangkan 8 sampel MAP $(+)$, yang menjadi preeklampsia ringan 1 $(12,5 \%)$. Pada kelompok kontrol dari 16 sampel ROT $(+)$, yang menjadi preeklampsia ringan $3(18,7 \%)$, sedangkan 8 sampel MAP yang menjadi preeklampsia ringan $1(12,5 \%)$ Hal ini terbukti pemberian vitamin E pada kelompok perlakuan dan aspirin pada kelompok kontrol dapat menurunkan angka kejadian preeklampsia. Resiko Relatif pada pernberian vitarnin E 1,33 kali lebih besar untuk terjadinya preeklampsia daripada pemberian aspirin Antara pernberian vitamin $E$ dan aspirin untuk mencegah preeklampsia pada primigravida yang cenderung 
preeklampsia tidak berbeda bermakna meskipun vitamin $\mathrm{E}$ bekerja lebih awal untuk mencegah dan menetralisir radikal bebas.

Masih terjadinya preeklarnpsia pada penelitian ini, menunjukkan bahwa etiologi preeklampsia multifaktorial. Beberapa kasus disebabkan oleh faktor imunulogik, yang lain oleh faktor genetik, diet dan masih banyak faktor lainnya, atau kombinasi antara faktor-faktor tersebut. Oleh karena itu sangat tidak mungkin hanya satu intervensi akan efektif mencegah preeklampsia (16).

\section{KESIMPULAN}

1. Vitamin E 100 IU dapat mencegah dan menurunkan kejadian preeklampsia serta dapat mencegah memberatnya preeklampsia.
2. Tidak ada perbedaan yang bermakna antara vitarnin $\mathrm{E}$ $100 \mathrm{IU}$ dan aspirin $81 \mathrm{mg}$ dalam mencegah dan menurunkan kejadian preeklamsia.

\section{SARAN:}

1. Pada waktu antenatal care dianjurkan melakukan deteksi dini terjadinya preeklampsia dengan cara sederhana yaitu MAP dan ROT.

2. Vitamin E sebagai antioksidan dan aspirin sebagai anti thromboksan diberikan pada primigravida untuk mencegah dan menurunkan terjadinya preeklampsia yang perneriksaan MAP dan ROT positip.

\section{DAFTAR KEPUSTAKAAN}

1. Cunningham GF, Gant FN, Leveno J, Gilstrap C, Hauth CJ. Hypertensive Disorders in Pregnancy. Williams Obstetrics 1997; 20: 693-744.

2. Kartha IBM. Hubungan Kadar Trigliserida Serum pada Umur Kehamilan Kurang dari 20 Minggu dengan Resiko Terjadinya Preeklampsia pada Primigravida. Majalah Obstetri dan Ginekologi Indonesia April 2000.

3. Sofoewan SHM. Fetal Outcome of Pre-EcImpsia and Eclampsia at DR. Sardjito Hospital. Symposium on Perinatology Yogyakarta. Februari 2000.

4. Oney T and Kaulhausen H. The Value of The Mean Arterial Bllod Pressure in The Second Trimester (MAP-2 Value) as a Predictor of Pregnancy-Induced Hypertension and Preeclarnpsia. Clin- and Exper Hyper In Pregnancy 1983.

5. Sukarya SW, Yamasi M, Morikawa H. The Influence of Dosahexanoic Acid and Vitamin E to The Pergnant Women. Simposium on Perinatology Yogyakarta. February 2000.

6. Roberts M.J. Is Oxidative Stress The Link in The Two Stage Model of Pre Eclampsia. The Lancet September 1999.

7. Suryohudoyo Purnomo. Oksidan, Antioksidan dan Radikal Bebas. Kapita Selekta Ilmu Kedokteran Molekuler 2000.

8. Walsh W Scott. The Role of Oxidative Stress and Antioxidants in preeclampsia. Contemporary OB/Gyn May 1997.

9. Walsh SW, Wang Y, Jesse R. Peroxide Induces Vasocontriction in The Human Placenta by Stimulating Tromboxane. Am J OB/Gyn 1993.

10. Wisdom SJ, Wilson R, McKillop J. Antioxidant System in Normal Pregnancy and in Pregnancy- Induce Ht. Ain J OB/Gyn 1991.

11. Leon S, Glass HR, Kase KN. Prostaglandins. 1994; 5.

12. Wang Y, Wals SW, Guo J, Zhang J. Maternal level of Prostacyclin, Tromboxane, Vitamin $E$ and Lipid Peroxides Throughout Normal Pregnancy. Am J of OB/Gyn 1991.

13. Wang Y, Wals SW, Guo J, Zhang J. The Imbalance between Tromboxane, and Prostacycline in Preeclampsia is Associated with an Imbalance between Lipid Peroxides and Vitamin E in Matemal Blood. Am J OB/Gyn 1991.

14. Champpell CL. Effect of Antioxidants on The Occurrence of Pre- Eclampsia in Women at Increased Risk. The Lancet September 1999.

15. Gumilar Erry D. Controversy in Low Dose Aspirin as Prevention of Preeclamsia. Symposium on Perinatology Yogyakarta. February 2000.

16. Heyborne D, Kent. Preeclarnpsia Prevention. Lesion from the low-dose aspirin therapy trial. Am J OB/Gyn. Septernber 2000; 183: 3. 